\title{
Sewage-induced disturbance on polychaetes inhabiting intertidal mussel beds of Brachidontes rodriguezii off Mar del Plata (SW Atlantic, Argentina)
}

\author{
RODOLFO ELÍAS, MARÍA S. RIVERO, JULIETA R. PALACIOS \\ and EDUARDO A. VALLARINO. \\ Departamento de Ciencias Marinas, Universidad Nacional de Mar del Plata. Deán Funes 3350 (B 7602 AYL), \\ Mar del Plata, Argentina. E-mail: roelias@mdp.edu.ar
}

\begin{abstract}
SUMMARY: Continuous and short-term disturbances are produced on intertidal Brachidontes rodriguezii mussel beds by the sewage outfall of Mar del Plata, SW Atlantic. The effects on the associated polychaetes living on and between mussels were investigated, in both the spatial and short-term temporal scales. Multivariate methods show that the polychaete fauna was influenced by tidal level, total amount of sediment accumulated between mussels, distance from the sewage outfall, organic carbon of interstitial sediments, and sewage volume before and after the summer season. Environmental variables in the water column fitted with a spatial and temporal organic gradient. Capitella 'capitata' sp. showed typical opportunistic behaviour in relation to organic enrichment, as did Neanthes succinea, both being numerically dominant near the sewage discharge. Cirratulus sp., Caulleriella alata, and Boccardia polybranchia were common at intermediate distances from the outfall. Syllis prolixa, S. gracilis, and Protoariciella uncinata reached their highest abundance at intermediate stations and were characteristic of the control site. Close to the outfall mussel density and dominance is low, and opportunist polychaetes successfully colonize organically enriched interstitial sediments. At intermediate distances from the outfall sediments retained by mussels reach their maximum values, and density of polychaetes is also high. The control station is characterized by monolayered mussel beds and very low diversity of polychaetes. Opportunistic polychaetes increase in response to shortterm increases of sewage discharge during the summer season (November-March).
\end{abstract}

Keywords: polychaetes, intertidal, mussel beds, organic pollution, sewage, spatial and before-after summer season distribution, SW Atlantic.

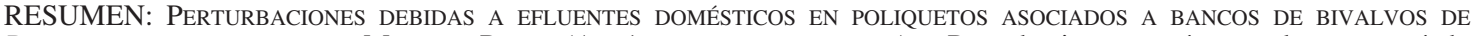
BRACHIDONTES RODRIGUEZII EN MAR DEL Plata (ATLÁNTICO SUDOCCIDENTAL). - Perturbaciones contínuas y de corto período de tiempo debidas a efluentes domésticos afectan a los bancos de los bivalvos Brachidontes rodriguezii en Mar del Plata, Atlántico sudoccidental. Se investigaron sus efectos sobre los poliquetos que viven asociados dentro y sobre los bancos, tanto en la escala espacial como la temporal (corto plazo). Métodos multivariados mostraron que los poliquetos estuvieron relacionados al nivel de marea, al total de sedimentos acumulados entre los bivalvos, a la distancia al efluente, al carbono orgánico total de los sedimentos y al volumen de descarga antes y después del verano. Las variables ambientales de la columna de agua estuvieron en concordancia con un gradiente de enriquecimiento orgánico espacial y temporal. Capitella 'capitata' sp. mostró el típico comportamiento oportunista en relación al enriquecimiento orgánico, al igual que Neanthes succinea, siendo ambas especies numéricamente dominantes cerca del efluente. Cirratulus sp., Caulleriella alata y Boccardia polybranchia fueron comunes a distancias intermedias del efluente. Syllis prolixa, S. gracilis y Protoariciella uncinata alcanzaron sus más altas abundancias a distancias intermedias, pero fueron características del sitio control. Cerca de la descarga del efluente la densidad y dominancia de bivalvos es baja, y los poliquetos oportunistas colonizaron exitosamente los sedimentos intersticiales enriquecidos orgánicamente. A distancias intermedias del efluente los sedimentos retenidos por los bivalvos alcanzaron sus mayores valores, y la riqueza de los poliquetos fue también alta. Las áreas control estuvieron caracterizadas por una monocapa de bivalvos y muy baja riqueza de poliquetos. Los poliquetos oportunistas incrementaron sus abundancias en respuesta al incremento del volumen de descarga en el período antes-después del verano (noviembre-marzo).

Palabras clave: poliquetos, intermareal, facies de mejillones, contaminación orgánica, aguas residuales, distribución espacial y estacional, Atlántico sudoccidental. 


\section{INTRODUCTION}

The response of macrobenthos to both spatial and temporal effects of sewage discharge in subtidal and intertidal habitats is well-known, on both hardbottoms and in muddy-sandy substrata (Pearson and Rosenberg, 1978). The opposite effect is also known, i.e. when an organically enriched discharge stops or is reduced (Moore and Rodger, 1991; Roberts et al., 1998; Archambault et al., 2001). However, in a coastal city of the Southwestern Atlantic (Mar del Plata, $38^{\circ} \mathrm{S}, 57^{\circ} \mathrm{W}$, ca. 550,000 inhabitants) an uncommon phenomenon occurs during a short period each year. About 2,000,000 people reach the city during the summer season, since it is the most popular seaside resort in Argentina. As a result of this increase in population, the intertidal sewage discharge increases from a mean continuous rate of 2.5 to $4 \mathrm{~m}^{3} / \mathrm{s}$. How does the marine ecosystem respond to this short-term or pulse disturbance (sensu Bender et al., 1984)? In subtidal areas near the outfall this increase has a significant effect on both the macrobenthic assemblages and environmental variables. The sewage-disturbance produces low macrobenthos diversity and poor environmental conditions, but periodic storms keep the environment healthy and return the macrobenthos to equilibrium (Elías et al., 2005). It is suspected that this pulse disturbance (i.e. an acute effect that eventually diminishes) has a major impact on the intertidal community rather than on communities in the subtidal zone.

The structure of the intertidal mytilid community on the SW Atlantic shore, characterized by Brachidontes rodriguezii, has been sucessfully used to detect environmental impact due to domestic sewage (López Gappa et al., 1990, 1993; Vallarino, 2002; Vallarino et al., 2002). The methodology is expensive in terms of sampling design, sorting and identification of all the organisms living in association with the mussel beds. On the other hand, López Gappa et al. (1993) have mentioned that the study of the associated flora and fauna of these mussel beds could be suitable for assessing organic enrichment due to sewage along the argentine coasts. In fact, the matrix of B. rodriguezii (like other mussel beds, see Tsuchiya and Nishihira, 1985; Seed and Suchanek, 1992; Tokeshi, 1995; Günther, 1996; Ragnarsson and Raffaelli, 1999; Damianidis and Chitiroglou, 2000) creates a secondary sediment habitat that is occupied by several species, including nemerteans, polychaetes and other infaunal invertebrates (Penchaszadeh, 1973; Scelzo et al., 1996).

Polychaetes are one of the most useful marine taxa for the detection of pollution because they live at the water-sediment interface which is biologically reactive and chemically active (Rhoads and Boyer, 1982). Polychaetes have been used in bioassays, monitoring of toxic compounds, and as pollution indicators, from the community or population level to the species level (Pocklington and Wells, 1992; Reish and Gerlinger, 1997). Presence or absence of some species, or even families, is known to be an indicator of contamination, in particular the presence of the Capitella complex or some spionids (Tsutsumi, 1990), or the absence of the genus Lumbrineris (Ryggs, 1985). Polychaetes associated with intertidal mussel beds of Brachidontes rodriguezii show classic behaviour in relation to an organic gradient, and have been successfully used as indicator species for assessing organic pollution of the SW Atlantic shore of Argentina (Elias et al., 2003). However, that study was limited to the spatial scale, and was carried out before the summer season impact. The present study analyses both spatial and temporal patterns, and also considers the tidal level. The temporal pattern tests the polychaete response to an increased sewage discharge due to the temporary increase of population in a major recreational city of the SW Atlantic in three 'before and after' summer seasons (November 1997-March 2000).

\section{Study area}

The sampling area is an open coast subjected to a longshore littoral current (south to north) and autumn-winter storms (Lanfredi, 1972; Isla and Ferrante, 1997), with vast sandy beaches only interrupted by cuarcitic outcrops and abrasion platforms of caliche (consolidate loess). Semidiurnal tides have a range of between $0.9 \mathrm{~m}$ and $0.6 \mathrm{~m}$. Seawater temperature ranges from $8-21^{\circ} \mathrm{C}$, and salinity varies between 33.5 and 33.8 psu, being considered as residual waters of the continental shelf (Lucas et al., 2000).

Sewage is discharged intertidally north of the city, with only a pretreatment that retains solids greater than $0.5 \mathrm{~mm}$. Adjacent to the sewage outfall, an abrasion platform (intertidal hard substratum) is abiotic to the north (except for a few opportunistic algae), but covered by a well developed mytilid community to the south, where the study was carried out. 


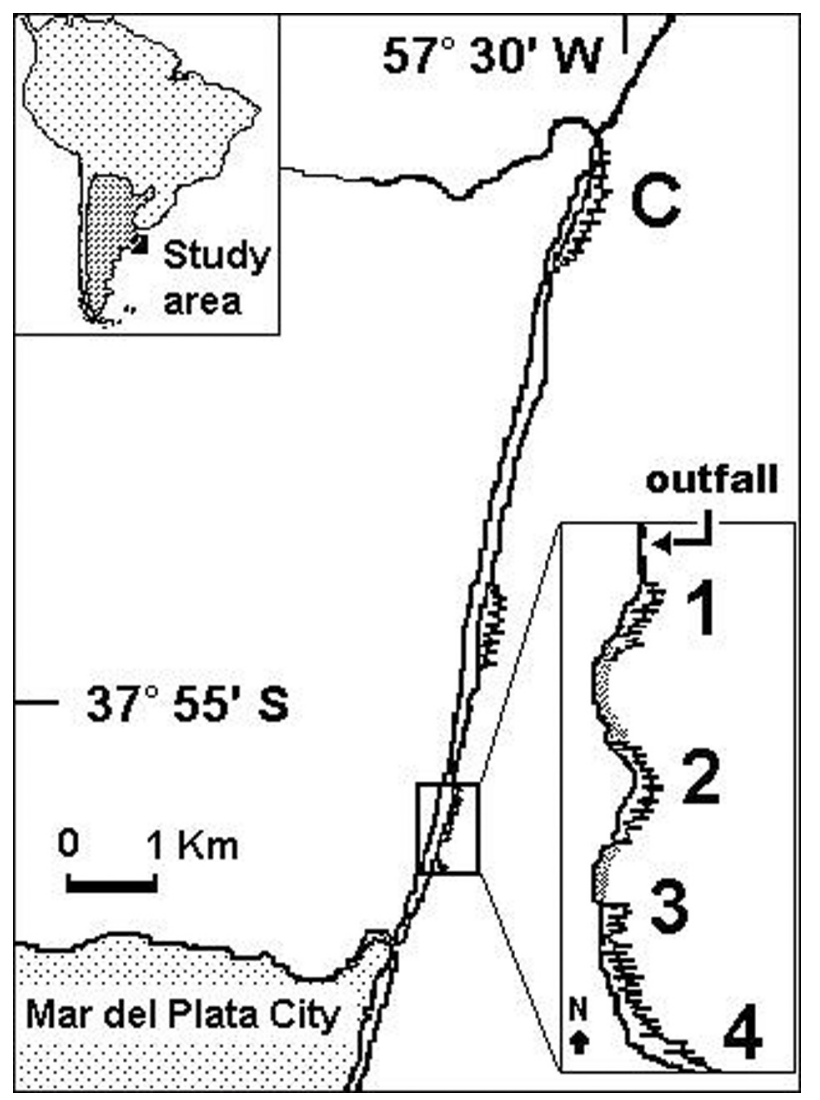

FIG. 1. - Sample stations in mussel beds of a Southwestern Atlantic shore exposed to an intertidal sewage discharge. C, a control station.

\section{METHODS}

Four stations south of the outfall were sampled, the first about $50 \mathrm{~m}$ to the south and the fourth some $725 \mathrm{~m}$ south of the outfall. Sampling was carried out at each station at two levels, the upper exposed during regular tides and the lower exposed only during extraordinarily low tides. At each sample point four random replicates were taken with a $78 \mathrm{~cm}^{2}$ cylindrical corer. A fifth station C (the control site) was also sampled in the Santa Elena Formation (also an abrasion platform), $9 \mathrm{~km}$ north of the outfall (Fig. 1). Each replicate was sieved using a $1 \mathrm{~mm}$ mesh, and the polychaetes living on and between the mussels were identified and counted.

Sediments accumulated between mussels in each replicate were retained during sorting for total weight estimation, while in situ samples of these sediments were obtained for Total Organic Carbon (TOC) content (Walkley and Black, 1965). Other environmental variables of seawater $(\mathrm{pH}$, dissolved oxygen, turbidity, salinity and temperature) were also measured in situ with a U-10 Horiba. Sampling was carried out before and after the summer season, during November 1997, 1998, 1999, and March 1998, 1999, 2000, respectively.

Water variables were analyzed using two-way ANOVA; each environmental variable vs stations and months (November and March) as factors. Sediment variables were analysed by two-way ANOVAs; one plotting total sediment retained between mussels vs upper-lower shore levels and stations, and the other with sediment vs stations and months. Other two-way ANOVAs analysed TOC in upper-lower levels, stations and months. These analyses were carried out despite the inability to sample at some lower levels on occasions (e.g. in station 1 and sometimes in 3), and at some other stations sampling was impossible on occasions due to inclement weather conditions. All environmental variables show homogeneity of variances (Cochran's C test), with sediments accumulated between mussels transformed as $\log _{10}(x+1)$.

Ordination of biological data with non-metric Multi-dimensional Scaling (n-MDS) was used to analyse quantitative data on polychaete abundance and distribution. Minimum stress was achieved using the transformation $\log _{10}(x+1)$. Due to the high total number of replicates at each station they were averaged prior to n-MDS analysis. A matrix of similarities between each pair of samples was calculated using the Bray-Curtis similarity index. This coefficient was adopted since it is not affected by joint absence and was sufficiently robust for marine data (Field et al., 1982). The significance of the groups outlined a priori (levels within impacted and control areas) was tested with two-way nested ANOSIM ("analysis of similarities"), and the organisms that most contributed to the differences observed among groups were found by means of the SIMPER ("similarity percentages"). The significance of the shortterm response (November vs March) of the macrobenthic community was also analysed by a oneway ANOSIM, followed by a SIMPER analysis. All analyses were performed using the PRIMER computer program package.

A parametric method, the Redundancy Analysis (RDA), was performed to assess the relationship between stations, abiotic parameters and polychaete abundances in the months November and March. The eight most abundant polychaete species were used for this analysis. The use of a parametric method in the temporal scale is justified because there is no pseudoreplication in time due to different sampling sites at each station. The analysis was performed using the Biplot routine of the Excel worksheet. 

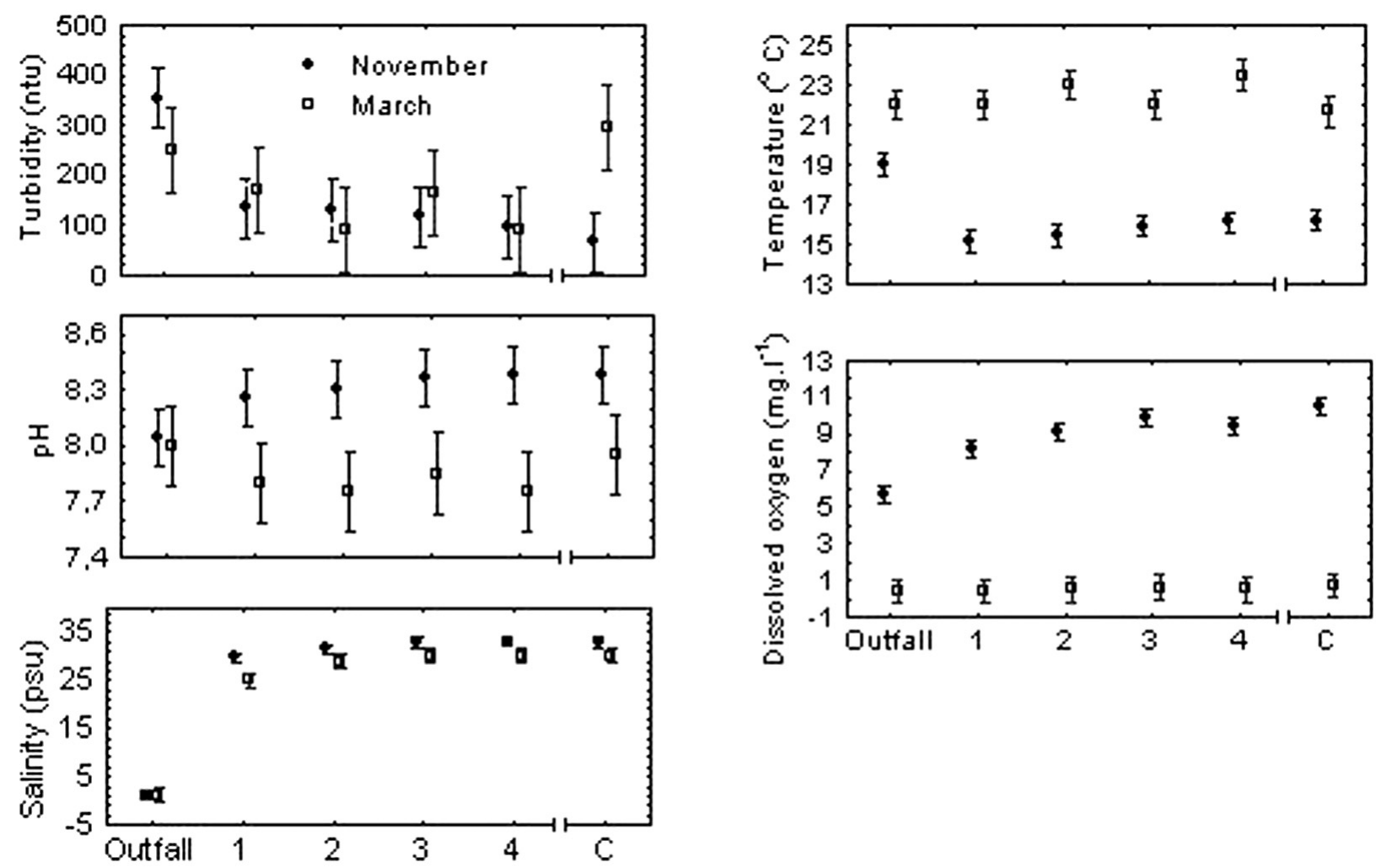

FIG. 2. - Mean data of environmental variables $( \pm$ sd) during November and March from an intertidal sewage outfall affecting intertidal mussel beds of a Southwestern Atlantic shore. (a) temperature, (b) salinity, (c) pH, (d), turbidity, (e) dissolved oxygen. In (e) no data from the outfall were available in March.
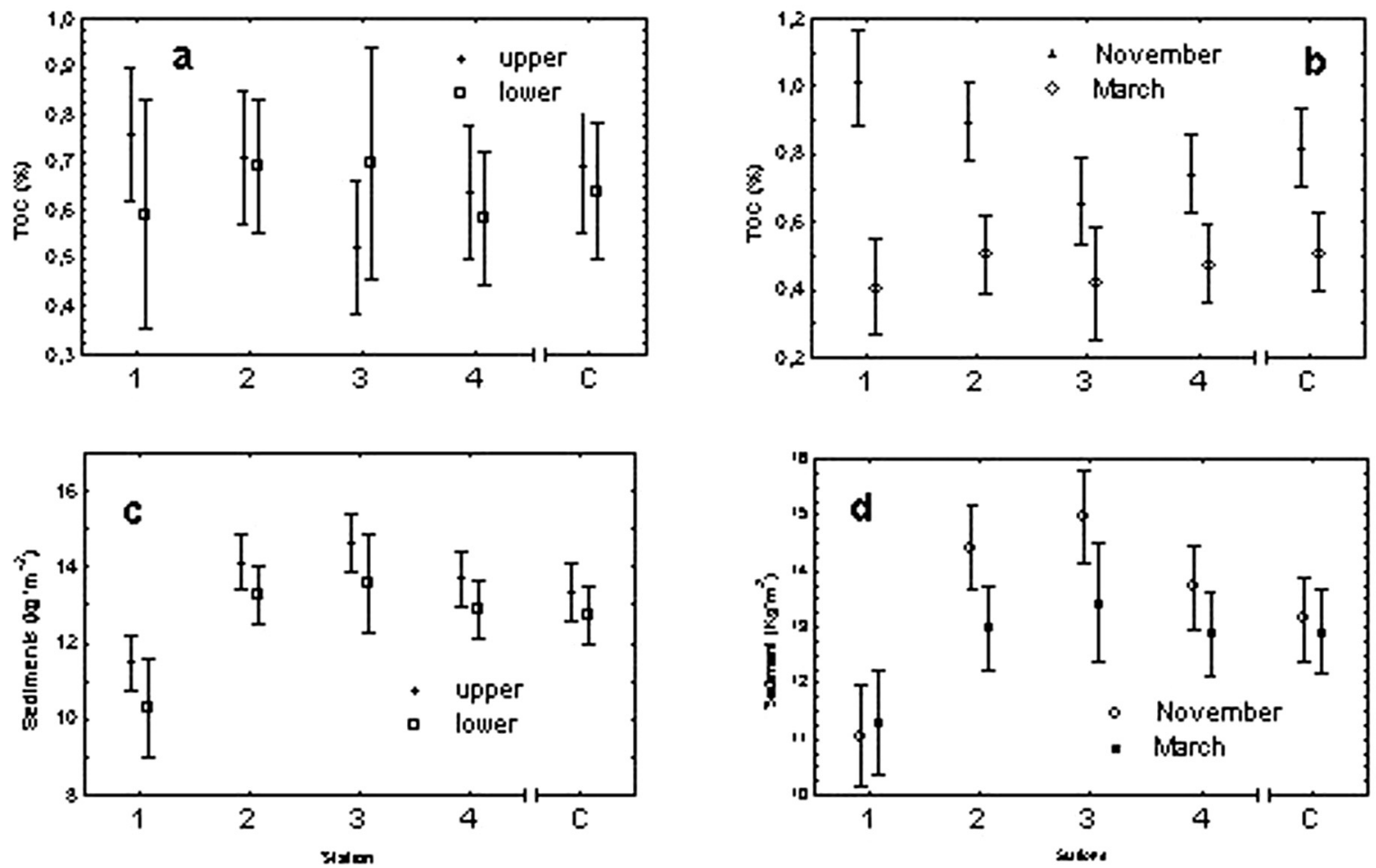

FIG. 3. - Mean data $( \pm$ sd) of total organic carbon at the sample stations,(a) at the upper and lower tide levels and (b) in November and March. Mean data of sediment accumulated between mussels at the sample stations, (c) at upper and lower tide levels and (d) in November and March. 
We have display untransformed data graphically, for a better understanding of the behaviour of both environmental variables and associated polychaetes in intertidal mussel beds.

\section{RESULTS}

\section{Water quality}

The variables measured (Fig. 2) show a pattern consistent with a gradient from the intertidal sewage outfall to the southernmost station 4 . All variables have highly significant differences $(\mathrm{p}<0.01)$ between the months November and March, while

TABLE 1. - Summary of all effects (Two-way ANOVA) in environmental data in an intertidal zone exposed to sewage. Month: November and March stations as in Figure 2, Variables: pH, turbidity, dissolved oxygen, temperature, salinity, sediment between mussels and total organic carbon. * $\mathrm{p}<0.05$; ** $\mathrm{p}<0.01$. The last column has the significant post hoc comparison (SNK test).

\begin{tabular}{|c|c|c|c|c|}
\hline Factor & Df effect & Ms effect & $\mathrm{F}$ & Post Hoc SNK \\
\hline \multicolumn{5}{|l|}{$\mathrm{pH}$} \\
\hline Month & 1 & 2.048 & $186.158 * *$ & \multirow{4}{*}{$\mathrm{C}$ vs 1 and 2} \\
\hline Station & 4 & 0.056 & $5.119 * *$ & \\
\hline Interaction & 4 & 0.010 & $0.916 \mathrm{~ns}$ & \\
\hline Error & 40 & 0.110 & & \\
\hline \multicolumn{5}{|l|}{ Turbidity } \\
\hline Month & 1 & 31559.76 & $7.017 * *$ & \\
\hline Station & 4 & 6564.79 & $1.459 \mathrm{~ns}$ & \\
\hline Interaction & 4 & 3433.16 & $0.763 \mathrm{~ns}$ & \\
\hline Error & 40 & 4497.46 & & \\
\hline \multicolumn{5}{|c|}{ Dissolved Oxygen } \\
\hline Month & 1 & 12.843 & $46.630 * *$ & \\
\hline Station & 4 & 2.477 & $8.996 * *$ & \multirow{3}{*}{1 vs all; 2 vs $C$} \\
\hline Interaction & 4 & 0.509 & $1.850 \mathrm{~ns}$ & \\
\hline Error & 20 & 0.275 & & \\
\hline \multicolumn{5}{|c|}{ Temperature } \\
\hline Month & 1 & 743.557 & $611.845^{* *}$ & \\
\hline Station & 4 & 0.250 & $0.206 \mathrm{~ns}$ & \\
\hline Interaction & 4 & 0.887 & $0.730 \mathrm{~ns}$ & \\
\hline Error & 40 & 1.215 & & \\
\hline \multicolumn{5}{|l|}{ Salinity } \\
\hline Month & 1 & 85.546 & $30.640 *$ & \\
\hline Station & 4 & 41.107 & $14.723 *$ & \\
\hline Interaction & 4 & 12.621 & $4.520 *$ & \\
\hline Error & 40 & 2.791 & & \\
\hline \multicolumn{5}{|l|}{ Sediment } \\
\hline Month & 1 & 27.742 & $8.034 * *$ & \multirow{4}{*}{1 vs all; 3 vs $C$} \\
\hline Station & 4 & 43.383 & $12.563 * *$ & \\
\hline Interaction & 4 & 5.290 & $1.532 \mathrm{~ns}$ & \\
\hline Error & 198 & 3.453 & & \\
\hline \multicolumn{5}{|c|}{ Total organic TOC } \\
\hline Month & 1 & 2.384 & $6.989 * *$ & \\
\hline Station & 4 & 0.504 & $1.477 \mathrm{~ns}$ & \\
\hline Interaction & 4 & 0.197 & $0.580 \mathrm{~ns}$ & \\
\hline Error & 59 & 0.341 & & \\
\hline
\end{tabular}

TABLE 2. - Ranking of total polychaete taxa in the mussel beds exposed to the sewage outfall. Dominance is the percentage of the total abundance of each species in relation to the total number of polychaetes.

Taxa

Dominance (\%)

Syllis prolixa

Boccardia polybranchia

46.0

Capitella 'capitata' sp.

Syllis gracilis

Protoariciella uncinata

Caulleriella sp.

Cirratulus sp.

Alitta succinea

Polydora sp.

Phyllodocidae

Lumbrineris tetraura

Polynoidae indet.

21.3
10.8
8.3
4.9
3.1
2.4
2.0
1.1
0.1
0.1
0.1

$\mathrm{pH}$ and dissolved oxygen also show highly significant differences between the stations. Salinity shows significant $(\mathrm{p}<0.05)$ interactions (Table 1$)$.

\section{Sediment analyses}

TOC (Fig. 3a) shows a gradient of organic enrichment from station 1 (closest to outfall) to station 4. However, minimum values were reached at station 3, and were slightly below those at the control site $(\mathrm{C})$. The differences were not significant between stations, but highly significant $(\mathrm{p}<0.01)$ between the sampling months (November is higher than March, Fig. 3b). Lower tidal levels show lower values in all but station 3 . Total sediment accumulated between the mytilids shows the opposite trend, being higher at the control site than near the outfall. Station 1 had the lowest value, and station 3 the highest (Fig. 3c). Differences were highly significant $(p<0.01)$ for

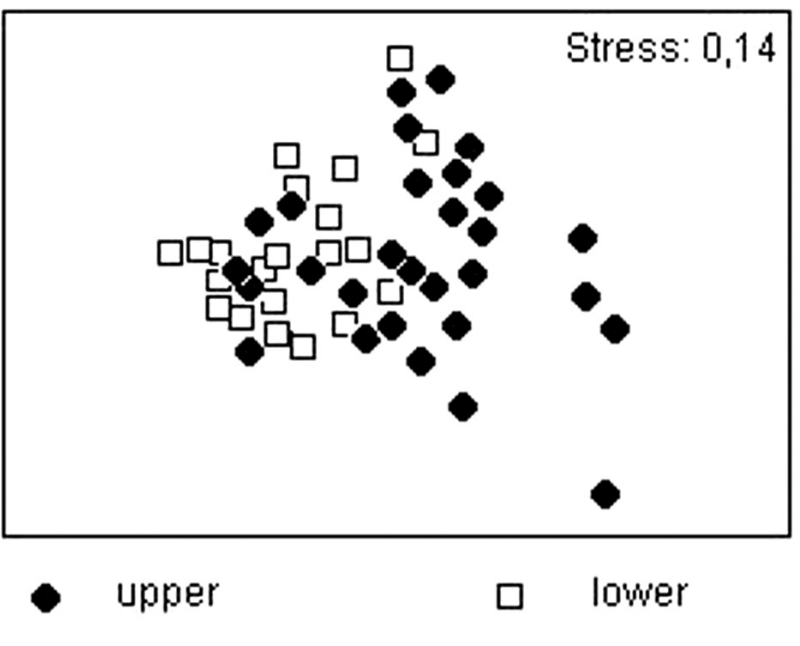

FIG. 4. - MDS Tide levels 


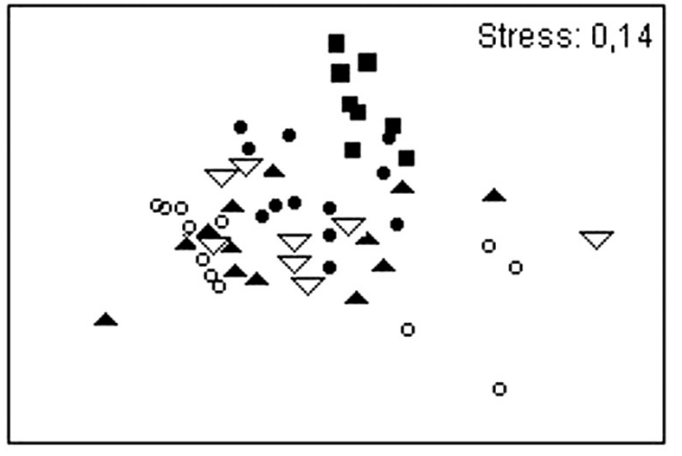

FIG. 5. - MDS Stations

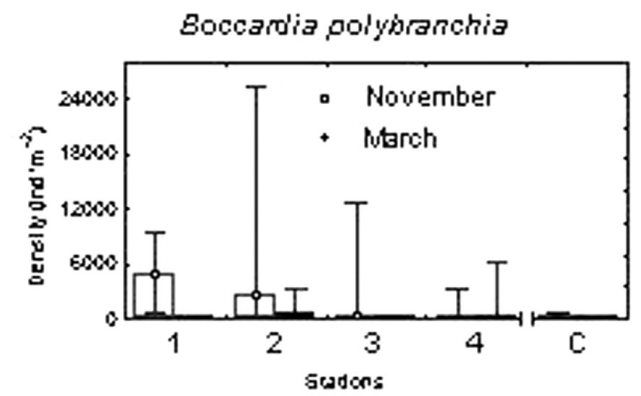

Caulleriella so.

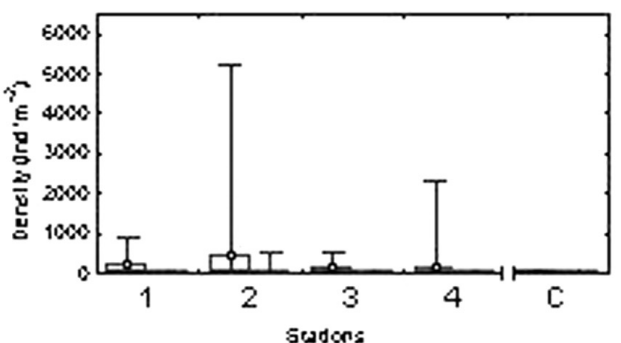

Syllis orolixa

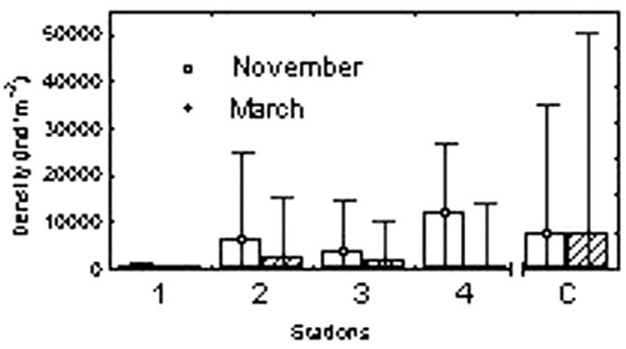

Protoariciella uncinata

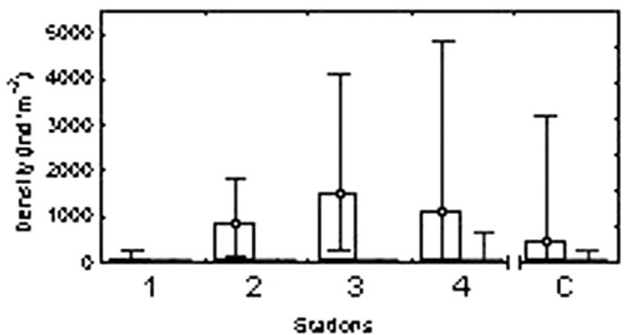

stations (station 1 vs all; station 3 vs C) and November had significantly higher values than March (Fig. 3d). Lower tidal levels had lower sediment values (Fig. 3c, Table 1).

\section{Polychaete response}

A total of 25271 individuals belonging to 12 taxa (Table 2) were identified from the 6 samplings analysed (November 1997, 1998, 1999, and March 1998, 1999, 2000).
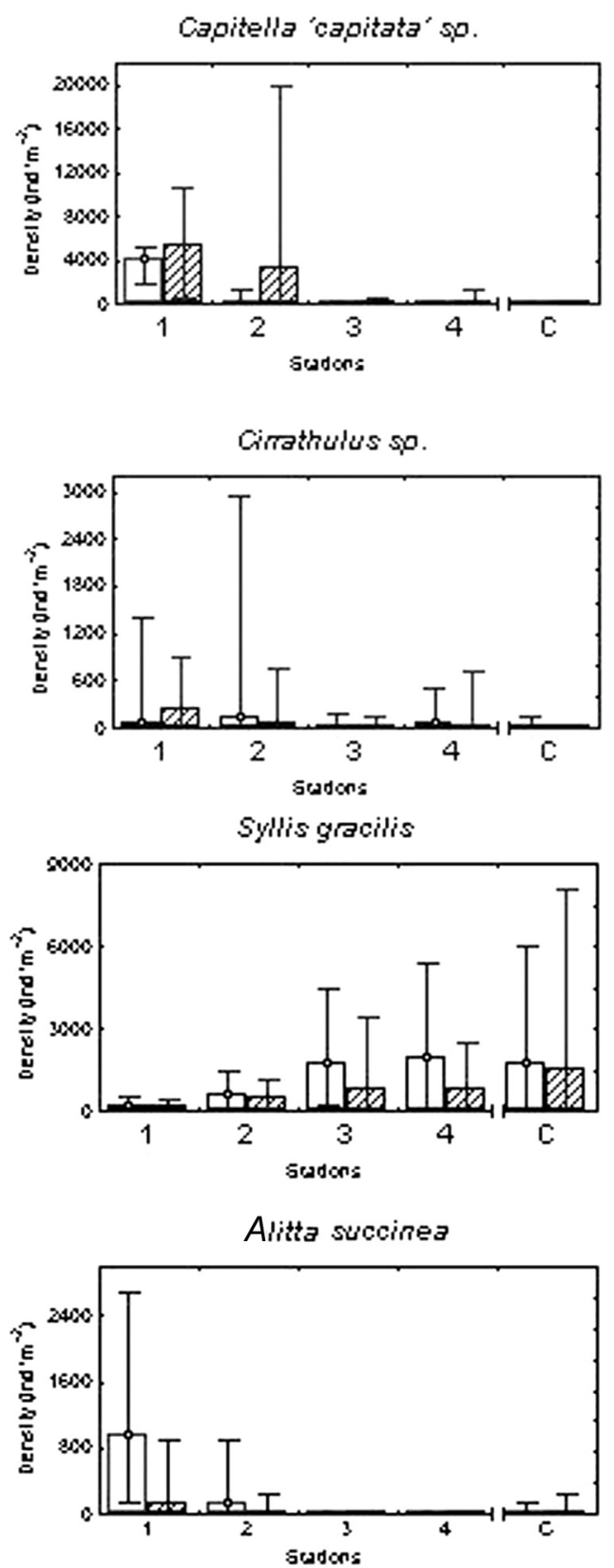

FIG. 6. - Median (25-75\% in box, 10-90\% in the bars) density (ind $\left./ \mathrm{m}^{2}\right)$ of main polychaete species associated with the intertidal mussel beds. Pattern of spatial distribution according to distance from the outfall and the November and March effect. 
TABLE 3. - Similarity percentages (SIMPER) at tide levels, in areas and months.

\begin{tabular}{|c|c|c|c|c|}
\hline \multicolumn{5}{|c|}{ Average dissimilarity: 48.91} \\
\hline Tide level & $\begin{array}{l}\text { Upper } \\
\text { Av. Abun. }\end{array}$ & $\begin{array}{l}\text { Lower } \\
\text { Av. Abun. }\end{array}$ & Contrib.\% & Cumul \% \\
\hline S. prolixa & 1.39 & 2.85 & 22.61 & 22.61 \\
\hline B. polybranchia & 1.62 & 0.87 & 16.44 & 39.05 \\
\hline C. 'capitata' sp. & 1.04 & 0.81 & 13.78 & 52.83 \\
\hline P. uncinata & 0.78 & 1.00 & 11.56 & 64.39 \\
\hline S. gracilis & 1.23 & 1.74 & 9.98 & 74.37 \\
\hline Caulleriella sp. & 0.32 & 0.88 & 9.78 & 84.15 \\
\hline Cirratulus sp. & 0.36 & 0.90 & 8.96 & 93.10 \\
\hline \multicolumn{5}{|c|}{ Average dissimilarity: 53.75} \\
\hline \multirow[t]{2}{*}{ Sample areas } & Impacted & Control & & \\
\hline & Av. Abun. & Av. Abun. & Contrib.\% & Cumul \% \\
\hline S.prolixa & 1.92 & 2.32 & 21.37 & 21.37 \\
\hline B. polybranchia & 1.46 & 0.76 & 16.62 & 37.99 \\
\hline C. 'capitata' sp. & 1.23 & 0.00 & 16.22 & 54.21 \\
\hline S. gracilis & 1.42 & 1.54 & 12.49 & 66.70 \\
\hline P. uncinata & 0.88 & 0.85 & 11.46 & 78.16 \\
\hline Cirratulus sp. & 0.69 & 0.24 & 7.75 & 85.91 \\
\hline Caulleriella sp. & 0.68 & 0.14 & 7.75 & 93.60 \\
\hline \multicolumn{5}{|c|}{ Average dissimilarity: 48.67} \\
\hline \multirow[t]{2}{*}{ Month } & November & March & & \\
\hline & Av. Abun. & Av. Abun. & Contrib.\% & Cumul \% \\
\hline S.prolixa & 2.19 & 1.82 & 18.73 & 18.73 \\
\hline$P$. uncinata & 1.45 & 0.25 & 16.57 & 35.30 \\
\hline B. polybranchia & 1.58 & 1.00 & 16.57 & 51.87 \\
\hline C. 'capitata' sp. & 0.75 & 1.15 & 14.44 & 66.31 \\
\hline S.gracilis & 1.53 & 1.36 & 9.60 & 75.91 \\
\hline Caulleriella sp. & 0.79 & 0.31 & 9.20 & 85.12 \\
\hline Cirratulus sp. & 0.61 & 0.56 & 7.78 & 92.89 \\
\hline
\end{tabular}

A two-way nested ANOSIM ( tide levels within impacted and control station, averaged across all area or tide level groups) shows that differences due to tide levels are significant (Global R: 0.171, $\mathrm{p}=$ $0.3 \%$, Fig. 4 ), as well as between the impacted area (stations 1-4) and the control station (Global R: $0.75, \mathrm{p}=33.3 \%$, Fig. 5). Boccardia polybranchia and Capitella 'capitata' sp. are more abundant at both the high tide level and the impacted stations, while the other species are more abundant at lower tide levels and at the control station (Table 3).

The one-way ANOSIM between November and March shows that differences were significant (Global R: 0.141, $\mathrm{p}=0.2 \%$, Fig. 6). All species apart from Capitella 'capitata' sp. were more abundant in November.

\section{Relationship of environmental variables and polychaete distribution.}

The Redundancy Analysis (Fig. 7) shows polychaete distribution along axis I (explaining 62\% of total variance). At one side, Capitella 'capitata'sp.,

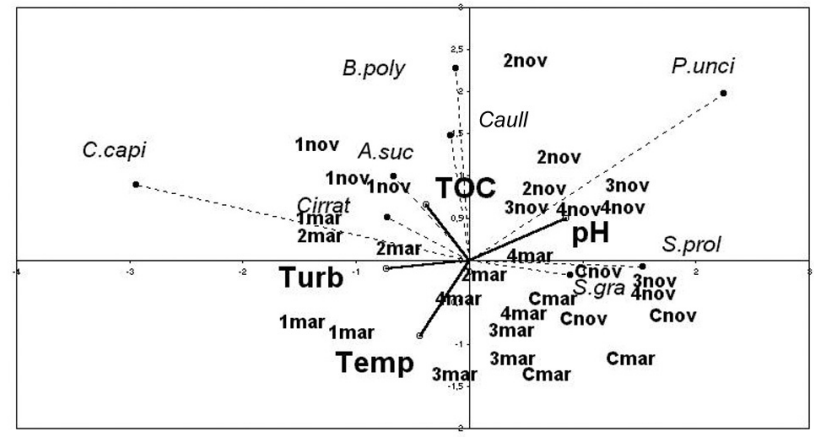

FIG. 7. - Redundancy Analysis. Station number includes nov for November, and mar for March period. Environmental variables are Turb: turbidity, TOC: Total Organic Carbon, Temp: temperature, DO: dissolved oxygen, and pH. Species are A.suc: Alitta succinea, C.capi: Capitella 'capitata' sp., Cirrat: Cirratulus sp., Caull: Caulleriella sp., B.poly: Boccardia polybranchia, P.unci: Protoariciella uncinata, S prol: Syllis prolixa, S.gra: Syllis gracilis.

with Alitta succinea, Cirratulus sp., Caulleriella sp. and Boccardia polybranchia were highly related to TOC and turbidity. Station 1, the most impacted, was associated with these species. On the other side, Protoariciella uncinata, Syllis prolixa and S. gracilis where related to high values of $\mathrm{pH}$ and dissolved oxygen, as well as to stations far from the outfall. Stations were also distributed along axis II (explaining $31 \%$ of the total variance). Stations in November were placed in the positive values of the axis, and March stations in the negative values. High values of temperature and turbidity were related to March stations.

\section{DISCUSSION}

Environmental variables show differences according to the season (end of spring - end of summer in the Southern Hemisphere, e.g. temperature), but also due to an organic gradient from a sewage discharge. In particular, $\mathrm{pH}$ and dissolved oxygen show poor environmental conditions near the outfall, and also during March. Oxygen deficiency has been mentioned as the main ecological factor causing severe stress to macrobenthos (González-Oreja and Saiz-Salinas, 1999). In the same way, TOC shows high values near the outfall, reflecting high organic matter input in the area. On the other hand, a second gradient of the total sediment accumulated between mussels can be observed, being higher at the control station than near the outfall. This gradient is the result of sediment trapped by the mussel matrix due to their community structure (multi-layered). This is a common feature in mytilid beds 
(Seed and Suchaneck, 1992). Due to organic disturbance mussel cover and density decreases towards the outfall, and the matrix can retain less sediment. However, structural complexity reached its maximum at intermediate distances from the outfall, due to a combination of high density and an even distribution of juveniles and adult mussels (Vallarino, unpublished data, but see Vallarino et al., 2002). This fact leads to a major retention of sediments at intermediate stations. The location of station 3 in a little bay may also play a role in greater sediment accumulation here. The sediment accumulated between mussels is a density-dependent factor, while density of mytilid is a sewage-dependent process (Vallarino et al., 2002).

In response to this organic gradient, the indicator species Capitella 'capitata' sp. (see Reish, 1957; Pearson and Rosenberg, 1978; Tsutsumi, 1990; Pocklington and Wells, 1992) dominates areas closest to the outfall. Species of the Capitella complex have largely been found associated with mussel beds, either in the Mytilus matrix or in surrounding sediments (Günther, 1996). Capitella 'capitata' sp. responds markedly to the short-term sewage disturbance increasing at stations 1 and 2 during March.

Boccardia polybranchia reached highest densities in impacted stations (mainly in station 2) and also at the upper tide level. However, densities in March were lower than in November (except at the control station), suggesting a negative effect of high organic matter loading. In a spatial scale study (Elías et al., 2003) this species has been suggested as an indicator of organically enriched sediments. Boccardia spp. are also frequently mentioned as being in or around sewage outfalls in the Southern Hemisphere, like B. proboscidea (Dorsey, 1982) and also in California (Dorsey et al., 1983). B. polybranchia was described from an Australian sewage outfall, and is common in the Brachidontes community (see Blake, 1983). López Gappa et al. (1990) have found up to $500,000 \mathrm{ind} / \mathrm{m}^{2}$ of Boccardia sp. in adjacent sandbanks and in Brachidontes beds around a small sewage outfall $\left(0.16 \mathrm{~m}^{3} / \mathrm{s}\right) 120 \mathrm{~km}$ south of Mar del Plata City. The new evidence suggests that Boccardia polybranchia should be considered as tolerant of moderately enriched sediments.

Another species enhanced by sewage discharge was Alitta succinea. This species was formerly described for mixohaline waters of a coastal lagoon (Orensanz and Estivariz, 1971), and was also found among Brachidontes beds in vertical substrata of the breakwaters of Mar del Plata City (Scelzo et al., 1996). Alitta spp. have been found in or around organically polluted zones (Pearson and Rosenberg, 1978). A previous study (Elías et al., 2003) recorded A. succinea for the first time in impacted areas of the southwestern Atlantic. Its response to short-term sewage impact is not evident in the March plots, because its density was lower than in November, but it shows a relationship with organic matter in the RDA. The species should also be considered as an indicator of moderately enriched sediments.

The syllids of the area, Syllis prolixa and S. gracilis, increased in abundance with distance from the outfall. Their distribution was negatively related to high TOC and positively associated with high values of dissolved oxygen, $\mathrm{pH}$, and to the total sediment accumulated between mussels. Short-term response shows greater density values in November in all but control station (C). Density was greater at lower tide levels, with an increase in March, while at upper tide levels the opposite effect occurred. A Mediterranean syllid Syllis prolifera, is considered a 'clean water' species (Bellan, 1964; Bitar, 1982). S. prolixa is present in mytilid beds of the Magellan region (G. San Martín, pers. com.). Along the coastline of Peru Typosyllis (possibly a misidentification, most probably $S$. prolixa) is a common inhabitant of Semimytilus and Perumytilus mussel beds (Tokeshi, 1995). Syllids are also common in Brachidontes mussel beds (Olivier et al., 1966; Penchaszadeh, 1973), being indicators of high and midtidal levels on vertical substrata (Scelzo et al., 1996). At the spatial scale they reached maximum dominance and density at an intermediate distance from the outfall, and are negatively correlated with organic enrichment (Elías et al., 2003).

The diversity of polychaetes associated with Brachidontes beds (see Table 2) seemed to be lower than in other mussel beds. In the Mediterranean Sea, Mytilus galloprovincialis beds have between 30-48 polychaete species (Tsuchiya and Bellan-Santini, 1989; Damiandis and Chitiroglou, 2000), and about 30 species off Portugal (Saldanha, 1974). In France a comparison between mussel beds of polluted and clean waters showed little differencein the species diversity (13 to $14 \mathrm{spp}$, respectively) (BellanSantini, 1969), but in Spain Villalva and Viéitez (1985) found 40 species in unpolluted Mytilus beds but this reduced to 2-24 species at impacted sites. On the other hand, mussel beds of the southern Perumytilus and Semimytilus beds showed 21 to 25 
species respectively in Perú (Paredes and Tarazona, 1980), and only 6 in Chile (Tokeshi, 1995). In northern Japan Mytilus edulis beds have 14-19 species (Tsuchiya and Nishihira, 1986).

As summarized by the redundancy analysis, there is a spatial gradient of organic enrichment related to increasing distance from the outfall. Environmental variables reflected the poor conditions near the outfall, while farther from the source and at the control station the environment is healthy. Indicator polychaetes are present near the outfall (Capitella 'capitata' sp., Alitta succinea, Caulleriella sp., Cirratulus sp. and Boccardia polybranchia), but at the control station polychaetes are characteristic of an undisturbed community (syllids and Protoariciella). The spatial trend herein observed is in agreement with the spatial pattern previously described (Elías et al., 2003). There is also a temporal pattern produced by the short-term response of polychaetes to an increase of the sewage discharge between November and March. Stations at intermediate distances from the outfall show signs of organic enrichment in March, in response to increasing sewage discharge during the summer.

Elías et al. (2005) have shown that subtidal macrobenthic assemblages in the area support two major short-term disturbances: sewage and storms. In the period November-March increased sewage volume has a highly significant effect on water quality, sediment properties, and the macrobenthic infauna of subtidal areas. Periodic storms return all variables to previous conditions. In intertidal areas polychaetes, as well as the whole intertidal community (Vallarino, unpublished data), showed the same rapid response to the short-term increasing organic enrichment, except for organic matter in the sediments retained by mussels. The fact that both sediments between mussels and organic carbon content suffer a significant reduction in March suggests a possible response to storms. However, further studies are needed to assess the effect of storms on the intertidal community.

\section{ACKNOWLEDGEMENTS}

We are grateful to Vasily Radashevsky for identifying the spionid polychaetes. Dr. Claudia S. Bremec (CONICET-INIDEP) also helped in polychaete identification. The company Obras Sanitarias Sociedad de Estado (OSSE) provided funding (from 1999) to con- tinue the project. Dr. J. López Gappa and Paulo da C. Lana kindly read the manuscript and suggested modifications that have improved the work.

\section{REFERENCES}

Archambault, P., K. Banwell and A.J. Underwood. - 2001. Temporal variation in the structure of intertidal assemblages following the removal of sewage. Mar. Ecol.Prog. Ser., 222: 51-62.

Bender, E.A., T.J. Case and M.E. Gilpin. - 1984. Perturbation experiments in community ecology: theory and practice. Ecology, 65: 1-13.

Bellan, G. - 1964. Contribution a l'étude systématique, bionomique et écologique des annélides polychétes de la Méditerranée. Rec. Trav. Sta. Mar. Endoume, 49(Bull. 33): 1-372.

Bellan-Santini, D. - 1969. Contribution à l'etude des peuplements infralitoraux de susbtrats rocheux (Étude qualitative et quantitative de la frange supérieur). Rev. Trav. Sta. Mar. Endoume, 63(Bull. 47): 5-294.

Bitar, G. - 1982. Influence d'un grand émisaire urbain sur la distribution du zoobenthos de substrate dur dans la région de Marseille (Mediterranée Nord-occidentale). Tethys 10: 200-210.

Blake, J.A. - 1983. Polychaetes of the family Spionidae from South America, Antarctica, and adjacent seas and islands. Biology of the Antarctic Seas XIV. Antarct. Res. Ser., 39: 205-288.

Damianidis, P. and C.C. Chitiroglou. - 2000. Structure and functions of Polychaetofauna living in Mytilus galloprovincialis assemblages in Thermaikos Gulf (north Aegean Sea). Oceanol. Acta, 23: 323-337.

Dorsey, J.H. - 1982. Intertidal community offshore from the Werribee sewage-treatment farm: An opportunistic infaunal assemblage. Aust. Mar. Fresh. Res., 33: 45-54.

Dorsey, J.H., K. D. Green and R.C. Rowe. - 1983. Effects of sewage disposal on the polychaetous Annelids at San Clemente Island, California. In: D.F. Soule and D. Walsh (eds.), Waste Disposal in the Oceans. Minimizing Impact, Maximizing Benefits, pp. 209-233.

Elías, R., M.S. Rivero and E.A. Vallarino. - 2003. Sewage impact on the composition and distribution of polychaetes associated to intertidal mussel beds of the Mar del Plata rocky shore (Argentina). Iheringia, 93: 309-318.

Elías, R., J.R. Palacios, M.S. Rivero and E.A. Vallarino. - 2005. Short-term responses to sewage discharge and storms of subtidal sand-bottom macrozoobenthic assemblages off Mar del Plata city, Argentina (SW Atlantic). J. Sea Res., 53: 231-242.

Field, J.G., K.R. Clarke and R.M. Warwick. - 1982. A practical strategy for analyzing multispecific distribution patterns. Mar. Ecol. Prog. Ser., 8: 37-52.

Gonzáles Oreja, J.A. and J.I. Saiz Salinas. - 1999. Fitting response models of benthic community structure to abiotic variables in a polluted estuary system. Acta Oecol., 20: 471-477.

Günther, C.P. - 1996. Development of small Mytilus beds and its effects on resident intertidal macrofauna. P.S.Z.N.I: Mar.Ecol., 17: 117-130.

Isla, F.I. and A. Ferrante. - 1997. Corrientes. In: F.I. Isla (ed.), Estudio del sector de plataforma receptor de la descarga cloacal de Camet, Mar del Plata. Final repport to Obras Sanitarias Sociedad del Estado, Capítulo 5: 83-116.

Lanfredi, N.W. - 1972. Resultados de mediciones directas de corrientes en el Atlántico Sud-occidental. Serv. Hidr. Naval, H650/2, Buenos Aires, 107 pp.

López Gappa, J.J., A. Tablado and N.H. Magaldi. - 1990. Influence of sewage pollution on a rocky intertidal community dominated by the mytilid Brachydontes rodriguezi. Mar. Ecol. Prog. Ser., 63: 163-175.

López Gappa, J.J., A. Tablado and N.H. Magaldi. - 1993. Seasonal changes in an intertidal community affected by sewage pollution. Environ. Pollut., 82: 157-165.

Lucas, A., R. Guerrero, H.W. Mianzan; M.E. Acha and C. Lasta. 2000. On the coastal oceanographic regimes of northern argentine continental shelf. Abstracts of the IV's Jornadas de Ciencias del Mar, Puerto Madryn, Argentina. p. 84. 
Moore, D.C. and G.K. Rodger. - 1991. Recovery of a sludge dumping ground. II. Macrobenthic community. Mar. Ecol. Prog. Ser., 75: 301-308.

Olivier, S.R.; A. Escofet; J.M. Orensanz; S.E. Pezzani; A.M. Turro and M.E. Turro. - 1966. Contribución al conocimiento de las comunidades bénticas de Mar del Plata. I. El litoral rocoso entre Playa Grande y Playa Chica. An. Com. Invest. Cient. Prov. Bs. As., 7: 185-206.

Orensanz, J.M. and M.C. Estivariz. - 1971. Los anélidos poliquetos de aguas salobres de la Provincia de Buenos Aires. Rev. Mus. La Plata, Zool., 11: 95-114.

Paredes, C. and J. Tarazona. - 1980. Las comunidades de mitílidos del mediolitoral rocoso del Departamento de Lima. Rev. Per. Biol., 2(1): 59-72.

Pearson, T.H. and R. Rosenberg. - 1978. Macrobenthic succession in relation to organic enrichment and pollution of the marine environment. Oceanogr. Mar. Biol. Ann. Rev., 16: 229-311.

Penchaszadeh, P. - 1973. Ecología de la comunidad del mejillín (Brachydontes rodriguezi, D'Orb.) en el mediolitoral rocoso de Mar del Plata (Argentina): el proceso de recolonización. Physis A, 32: 51-64.

Pocklington P. and P.G. Wells. - 1992. Polychaetes. Key taxa for marine environmental quality monitoring. Mar. Poll. Bull., 24: 593-598.

Ragnarsson, S.A. and D. Rafaelli. - 1999. Effects of the mussel Mytilus edulis L. on the invertebrate fauna of sediments. J. Exp. Mar. Biol. Ecol., 241: 31-43.

Reish D.J. - 1957. The relationship of the polychaetous annelid Capitella capitata (Fabricius) to waste discharges of biological origin. In: C.M. Tarzwell (ed.), U.S. Public Health Service Biological Problems in Water Pollution: 195-200.

Reish, D.J. and T.V. Gerlinger. - 1997. A review of the toxicological studies with Polychaetous annelids. Bull. Mar. Sci., 60: 584-607.

Rhoads, D.C. and L.F. Boyer. - 1982. The Effects of Marine Benthos on Physical Properties of Sediments. A Successional Perspective. In: P.L. McCall and M.J.S. Tevesz (eds.). AnimalSediment Relations, pp. 3-52. Plenum Publ. Corporation.

Roberts, D.E., A. Smith, P. Ajani and A.R. Davis. - 1998. Rapid changes in encrusting marine assemblages exposed to anthropogenic point-source pollution: a 'Beyond BACI' approach. Mar. Ecol. Prog. Ser., 163: 213-224.

Ryggs, B. - 1985.- Distribution of species along pollution-induced diversity gradients in benthic communities in Norwegian
Fjords Mar. Pollut, Bull , 16: 469-474

Scelzo, M.A., R. Elías, E.A. Vallarino, M. Charrier, N. Lucero and F. Alvarez. - 1996. Variación estacional de la estructura comunitaria del bivalvo intermareal Brachydontes rodriguezi (D’Orbigny, 1846) en sustratos artificiales (Mar del Plata, Argentina). Neritica, 10: 87-102.

Seed R. and T.H. Suchanek. - 1992. Population and community ecology of Mytilus. In: E Gosling (ed.), The mussel Mytilus: ecology, physiology, genetics and culture. Dev. Aquac. Fish. Sci., 25: 87-170.

Tokeshi, M. - 1995. Polychaete abundance and dispersion patterns in mussel beds: a non-trivial 'infaunal' assemblage on a Pacific South American rocky shore. Mar. Ecol. Prog. Ser., 125: $137-147$.

Tsuchiya, M. and D. Bellan-Santini. - 1989. Vertical distribution of shallow rocky shore organisms and community structure of mussel beds (Mytilus galloprovincialis) along the coasts of Marseille, France. Mesogée, 49: 91-110.

Tsuchiya, M. and M. Nishihira.-1985. Islands of Mytilus as a habitat for small intertidal animals: effect of island size on community structure. Mar. Ecol. Prog. Ser., 25: 71-81.

Tsutsumi, H. - 1990. Population persistence of Capitella sp. (Polychaeta: Capitellidae) on a mud flat subject to environmental disturbance by organic enrichment. Mar. Ecol. Prog. Ser., 63: $147-156$

Vallarino, E.A. - 2002. La comunidad bentónica intermareal de Brachidontes rodriguezii ( $D^{\prime} O r b$.) y su relación con el efluente cloacal de la ciudad de Mar del Plata $\left(38^{\circ} S\right)$. Ph. D. thesis, Universidad Nacional de Mar del Plata.

Vallarino, E.A., M.S. Rivero, M.C. Gravina and R. Elías. - 2002 The community-level response to sewage impact in intertidal mytilid beds of the Southwestern Atlantic and the use of the Shannon index to assess pollution. Rev. Biol. Mar. Oceanogr., 37: $25-33$

Villalba, A. and J.M. Viéitez. - 1985. Estudio de la fauna de anélidos poliquetos del substrato rocoso intermareal de una zona contaminada de la ría de Pontevedra (Galicia). 1 - Resultados biocenóticos. Cah. Biol. Mar., 26: 359-377.

Walkley, A. and A. Black. - 1965. Chapter 4. In: A. Black and J. Evans (eds.), Methods of soil analysis. Am. Soc. of Agron., 219 pp., Madison, USA.

Received July 9, 2004. Accepted August 5, 2005. 